\title{
Projektowanie w regionach odmiennych kulturowo - dialog o tożsamości
}

\author{
Jan Wrana \\ Politechnika Lubelska, Wydziat Inżynierii Budowlanej i Sanitarnej, \\ Samodzielna Pracownia Architektoniczna
}

\begin{abstract}
Streszczenie: Druga połowa XX wieku to okres otwierania się środowisk dotychczas niedostępnych, spowo- dowanych eksplozją ruchów narodowo wyzwoleńczych, próby konstruowania tożsamości ponadnarodowych (na przykład : tożsamości europejskiej, przy jednoczesnym uwzględnieniu wielowiekowej odrębności kulturowej poszczególnych państw, oraz przy stale rosnącej migracji, mającej wpływ na zwiększający się relatywizm wobec zasobów kulturowych państw przyjmujących emigrantów. Powracać zaczyna wielowarstwowy problem tożsamości lokalnej, wywodzącej się z tradycji „małych ojczyzn” z cennymi odmiennymi zasobami rodzimej tradycji
\end{abstract}

Słowa kluczowe: wielokulturowość, kultura lokalna, tradycja.

\section{Poszukiwania}

„Poszanowanie dziedzictwa kulturowego i historycznego nie oznacza bezkrytycznego powtarzania form z przeszłości. Znaczy natomiast interpretowanie prawdziwego znaczenia architektury, a przez to jej odnowe (rewaloryzację), nadawanie jej nowej roli w strukturze urbanistycznej"

KARTA MEGARIDE ${ }^{1}$

Droga poszukiwań - zakreślenie pola badawczego - poszukiwanie możliwości działania architekta w odmiennych kulturowo regionach, jest nierozłącznie związane ze swoistym powrotem do ontologii zawodu. Dlaczego podejmujemy wyzwania ? Jeśli przypomnimy sobie najprostsze określenie definiujące podstawowe cechy architekta : potrzeba poznania, potrzeba ekspansji myśli, potrzeba samorealizacji - będziemy bliscy odnalezienia odpowiedzi na postawione pytanie. Umiejętność wyzwalania inicjatyw w celach poznawczych, budowanie świadomości zagrożeń, niecierpliwość w podejmowaniu nowych doświadczeń w trudnych środowiskach planistycznych i urbanistycznych, a także możliwość przeprowadzenia badań w odmiennych kulturowo regionach - te ważne dla zawodu argumenty doprowadziły do aktywności zawodowej, nie pozbawionej obaw, polskich architektów, w obcych nam kulturowo regionach. W latach 70-tych i 80-tych nastąpiło otwarcie się środowiska architektów na nowe, dotychczas niedostępne rynki regionu kultur Bliskiego Wschodu i Północnej Afryki, a po zmianach systemowych, po roku 1989 stało się możliwe aktywne działanie w wolnym zawodzie architekta ${ }^{2}$.

1 KARTA MEGARIDE 1994.

2 Autor artykułu; w latach 1981-1989 przebywał w Libii reprezentując jedną z pierwszych firm Consultingowych „Wadeco” pełnił w latach 1986-1989) obowiązki z-cy rezydenta ds. opracowania i wdrożenia planu miasta Misurata oraz rewitalizacji centrum, prowadził przez 
Wybrane do analizy regiony to miejsca nawarstwiania się kultur, historii - gdzie zasoby, relikty różnych epok sztuki budowania, sztuki użytkowej, malarstwa, rysunku i rzeźby koegzystują z tętniącym życiem współczesnych aglomeracji. To regiony Morza Śródziemnego - północna Afryka, region Bliskiego Wschodu Półwysep Arabski, region Wielkiej Rusi, - których historia odbiła się jak w lustrze we współczesnej architekturze, detalu, zdobnictwie, czego dowody możemy podziwiać do dziś.

To miejsca powstawania nowych kultur, trzech wielkich religii objawionych (zjawisk kulturowych i cywilizacyjnych: judaizmu (,Żydzi to najbardziej odporny naród w dziejach. Hebron jest tego dowodem”3), chrześcijaństwa („Boże słowo wcieliło się w dokładnie oznaczonym momencie, w określonej społeczności i kulturze, pośród konkretnego ludu." ${ }^{4}$ ), islamu (religii będącej syntezą judaizmu i chrystianizmu - początek od 622 roku (hidźry) ${ }^{5}$ oraz kultury bizantyjskiej jak też religii i kultury prawosławia (badając tło kulturowe powstania i rozwoju prawosławia na terenach Rusi, nie sposób nie wspomnieć o okresie powstania nad Bosforem wschodniej części imperium rzymskiego i rozwoju kultury bizantyjskiej ${ }^{6}$ ), oraz ich uczestnictwo we wzbogacaniu wielo kulturowych nawarstwień w europejskiej rodzinie „małych ojczyzn” (regiony - gdzie autor artykułu spędził zawodowo wiele lat).

Metodologia badań: wkraczając w „nowy świat kulturowy”, badania należy rozpocząć od poszukiwań źródeł i kontekstu lokalnej tradycji kulturowej - od trady-

kilka lat pracownię architektoniczno-urbanistyczną przy Urzędzie miasta (Baladyji) Misurata, kierując kilkudziesięcioosobowym zespołem; w latach 1994-1996 po uzyskaniu licencji samodzielnego projektowania na terenie Federacji Rosyjskiej, przebywał z przerwami po zmianach systemowych w Rosji ; opracowując i wdrażając rewitalizację głównego placu i ciągów historycznych w Riazaniu w konsultacji z architektem miasta Riazania L. W. Woroninem. Wybrane studia, koncepcje i projekty rewaloryzacji zespołów urbanistycznych:

1) Studium rewaloryzacji starego miasta w mieście Misurata (Libia) -1986-1989 r. (wdrożone) - opracowanie na miejscu, (od mapowania przez studia historyczne, inwentaryzację urbanistyczną, prognozowanie, po projekt i realizację), przekazane do wdrożenia, nadzór nad realizacją.

2) Studium, koncepcja, projekt realizacyjny rewitalizacji centrum miasta oraz historycznych ciągów handlowych (Riady) w Riazaniu (Rosja) 1994-1995 r. (realizacja), po uzyskaniu licencji do projektowania na terenie federacji Rosji wykonywał część opracowań na miejscu (inwentaryzacja, studia historyczna, koncepcja), projekty budowlane, projekty wykonawcze, + nadzór nad realizacją.

W latach 2004/2005/2006 autor artykułu przemierza wielokrotnie kraje Białoruś i Ukraina uczestnicząc w tym czasie w seminariach i konferencjach naukowych.

\section{P. Johnson, Historia Żydów, Kraków 2004.}

4 Andrea Dué, Dzieje 2000 lat Chrześcijaństwa, Edycja Świętego Pawła, Częstochowa, 2000

5 Albert Hourani, Historia Arabów, Gdańsk 1995, Teresa Kelm, Architektura sakralna Sahary, Arkady 2000, Barbara Stępniewska-Holzer, Życie codzienne na Bliskim Wschodzie w XIX wieku, PIW, Warszawa 2002.

6 R. Browning, Justynian i Teodora, Warszawa 1977, C. Mango, Historia Bizancjum, Gdańsk 1997, A. Bujak RUŚ. Tysiąc lat chrześcijaństwa. Warszawa1992, M. Angold, Cesarstwo Bizantyjskie 1025-1204. Historia polityczna. Wrocław 1993., B. Rybakow, Pierwsze wieki historii Rusi. Warszawa 1983. 
cji i historii osadnictwa badanego regionu. Trzeba poznać zasady, wedle których powstał badany zespół architektoniczny. Badania archiwalne i biograficzne opierać się winny na analizie dostępnych źródeł, wydawnictw naukowych i informacyjnych. Nie bez znaczenia dla zrozumienia wielowątkowego stanu substancji architektonicznej jest poznanie nawarstwień kulturowych badanego terenu. Wnioski wynikające ze studiów historycznych, poparte są rozszerzoną dokumentacją stanu istniejącego : szczegółowe opracowania faktograficzne - fotografie zachowanych obiektów, ich detali, charakterystycznych cech architektury i jej ornamentyki, rysunki i szkice posługujące się resztkami ocalałych fragmentów budowli w celu odkrycia ich pierwotnego, obecnie zdewastowanego kształtu, rozszerzenie poszukiwań na bezpośrednie sąsiedztwo terenu, który ma się stać przyszłym placem budowy, próba wyobrażenia sobie dawnej i przyszłej perspektywy, wyznaczonej przez koncepcję, projekt i realizację. Trzeba podkreślić fakt, iż prace: a) opracowanie i wdrożenie nowego Planu miejscowego Miasta Misuraty dla 350000 mieszkańców oraz Studium rewaloryzacji Starego Centrum Miasta Misuraty (miasto $40 \mathrm{~km}$ od stolicy kolonialnej regionu północnej Afryki imperium rzymskiego - Leptis Magna), projekty oraz realizacje w regionie północnej Afryki, regionu kultury muzułmańskiej, b) studium, projekt i realizacja rewitalizacji centrum miasta oraz historycznych ciągów handlowych (Riady) w Riazaniu w regionie kultury prawosławnej (w okresie zmian systemowych i przywracaniu rodowodu kulturowego), - wykonywane były na miejscu w rzeczywistości tętniącej życiem w odmiennych kulturowo społeczeństwach. Każdy spacer ulica, kawa i czaj w kawiarni, zakupy na „suku” lub targu, odwiedziny u nowych znajomych dostarczały wiedzy o tym, czego nie można ani przeczytać, ani zatrzymać na fotografii : jak żyją, jak myślą, jak działają - co budzi ich uśmiech, a co niechęć. Ta fizyczna obecność w mieście, którego plan miał wkrótce znaleźć się w opracowaniu, miejsce wskazane do kreatywnej architektonicznej ingerencji w istniejący zespół zabudowy, stała się nieodzownym uzupełnieniem prowadzonych poszukiwań. Wierność samemu sobie nakazuje jednak zachowanie dystansu wobec presji środowiska i historii. Pozostaje doświadczenie i pamięć, że można wspierać tych, którzy starają się znaleźć klucz do regionalnych dylematów, nie niszcząc i nie lekceważąc narodowej dumy i wrażliwości na wpływy z zewnątrz. Okazuje się więc, tak jak i w wielu sytuacjach nie związanych tylko z architekturą, że uwaga poświęcona nowemu wyzwaniu przynosi owoce w postaci współpracy z konkretnymi ludźmi, odkrycie z nimi „wspólnego języka”, stworzenie podstaw dla przyjaźni i zaufania.

\section{Rewaloryzacja edukacyjna}

Prowadzone doświadczenia w odmiennych regionach kulturowych, poszukiwanie rodowodu kulturowego to określenie (tła historycznego i kulturowego), określenie historycznych nawarstwień wpływów kultur: żydowskiej, chrześcijańskiej, muzułmańskiej prawosławnej oraz formowanie zasobów przestrzeni zbudowanej wraz z oceną zakresu rewitalizacji przy jednoczesnym udziale oraz partycypacji społeczności lokalnej. Po zmianach systemowych, oraz rozpoczętym procesie uświa-

\footnotetext{
7 Suk - targowisko, plac z całym zespołem obiektów handlowych. Nazwa ta obejmuje również dzielnicę handlową sąsiadującą z rynkiem, a także zespół targowisk. Poszczególne specjalności, towary i usługi usytuowane są w odpowiedniej hierarhii, począwszy od meczetu, od najbardziej szlachetnych (tkaniny, biżuteria) do podstawowych (żywność).
} 
damiania złożoności kulturowego dziedzictwa, przyjęta otwartość rynku projektowego umożliwiła w złożonych wielokulturowych zdegradowanych regionach podejmować interwencje regeneracji przestrzeni zbudowanej i przyrodniczej poprzez aktywne badania historyczne, prace archeologiczne oraz edukacyjne. Jednocześnie konieczne propagowanie aktywnego uczestnictwa mieszkańców miasta w jego rozwój, prowadzenie dialogu o świadome życie w środowisku zbudowanym jest drogą powszechnego inwestowania w edukację społeczną.

Przykłady:

a) region morza śródziemnego - miasto Misurata (Libia - region kultury muzułmańskiej), rozpoznanie tła historycznego, tła kulturowego, dla opracowania planu szczegółowego miasta, ukształtowania głównego placu miejskiego (rewitalizacji centrum) oraz interwencji projektowych. (projekty i realizacje)

a)

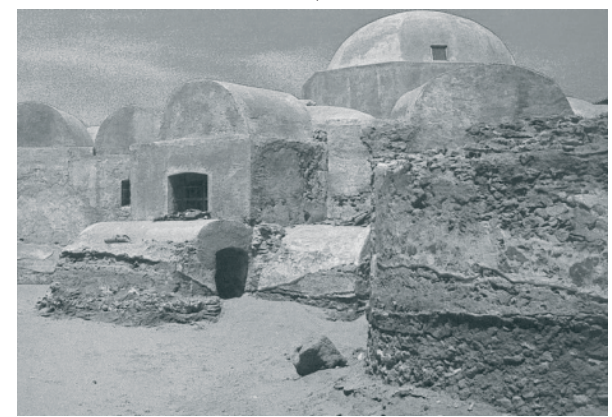

c)

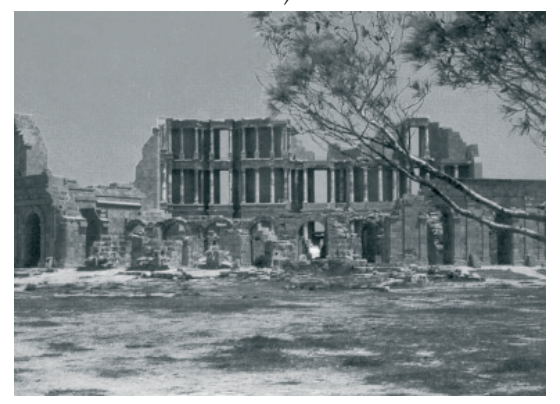

e)

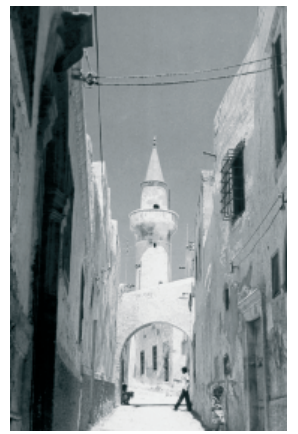

b)

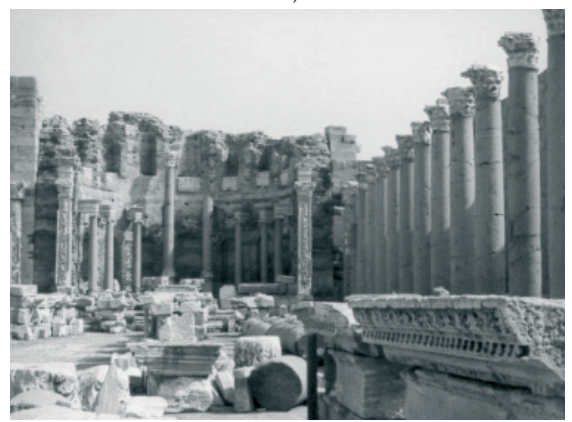

d)

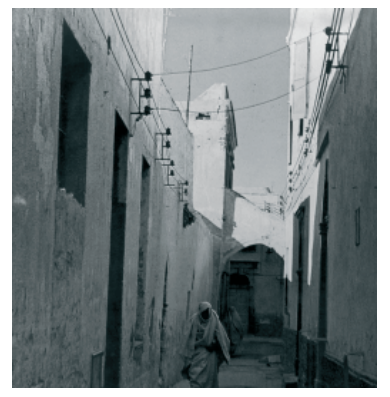

g)

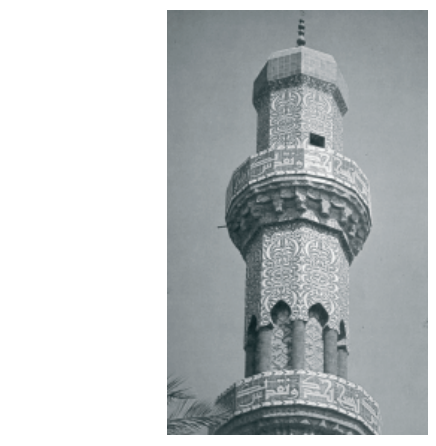

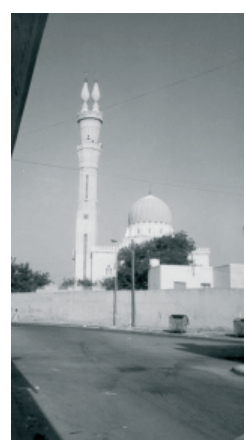

f) 
h)

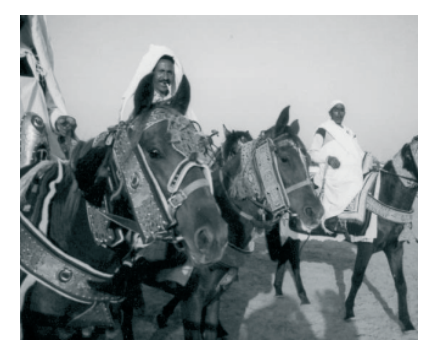

k)

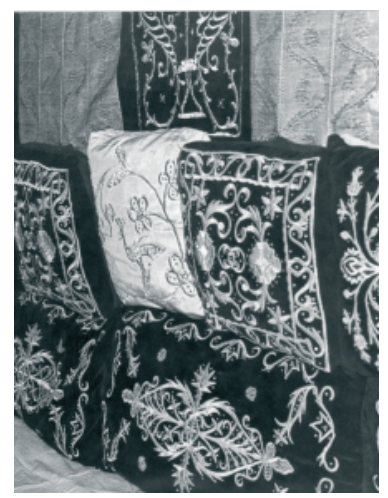

$\mathrm{m})$

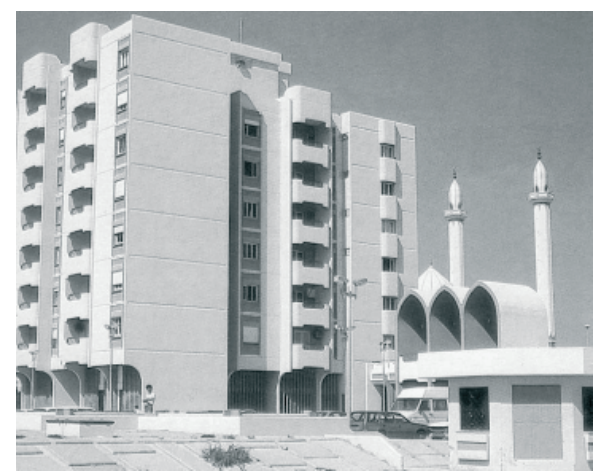

i)

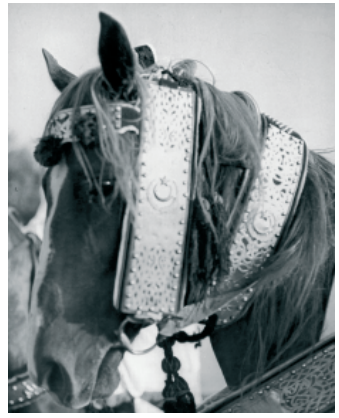

j)

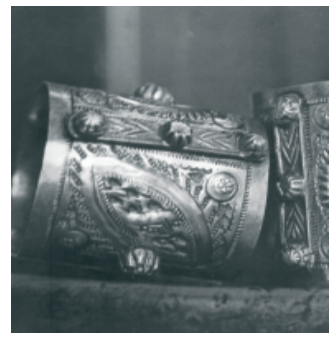

1)

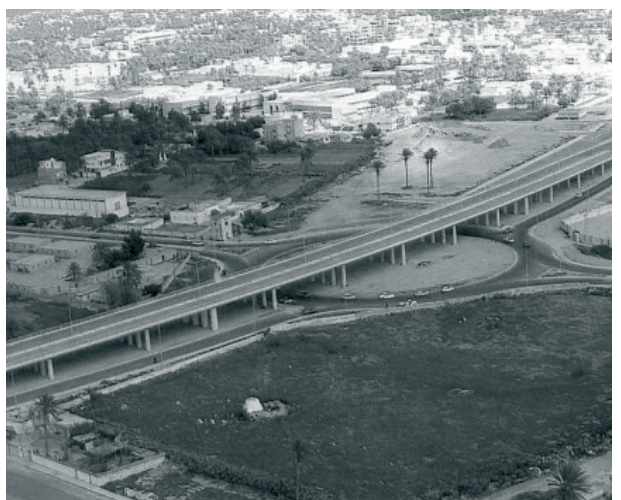

n)

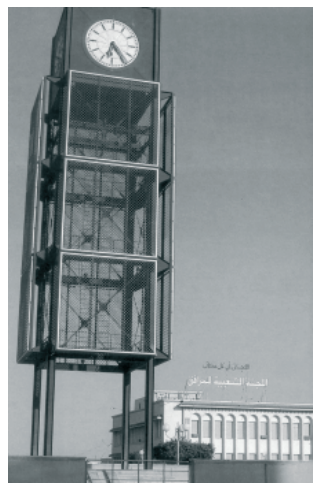

Phot. 1. a) Villa Selena II-gi w. n.e.(kolonia rzymska), b) Leptis Magna stolica kolonii rzymskiej (bazylika wczesnochrześcijańska), c) Sabratha - teatr rzymski, d) ulice starego miasta e) f) meczety na starym mieście, g) geometryczna ornamentyka zdobiąca minaret, h) mieszkańcy regionu na odświętnie udekorowanych koniach, i) uprzęże dekoracyjne konia, j) ozdoby kobiece ze srebra, k) ozdobne hafty regionalne, l) Współczesny węzeł komunikacyjny podwiązanie komunikacyjne miasta Misuraty, m) Architektura nowej zabudowy miasta, n) wieża zegarowa - symbol współczesnego miasta. 
b) region wielkiej Rusi - miasto Riazań (Rosja - region kultury prawosławnej), rozpoznanie tła historycznego, tła kulturowego, dla opracowania rewitalizacji placu miejskiego - „Chlebnaja Płoszczad” ${ }^{8}$ oraz interwencji projektowych „Riady”. (projekt i realizacja) w 900 - tnąrocznicę powstania miasta.

a)
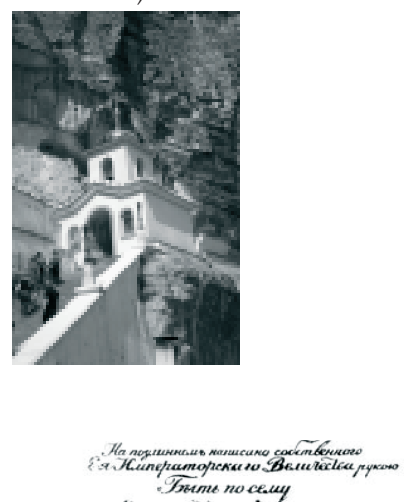

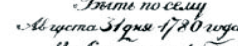

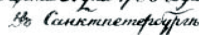

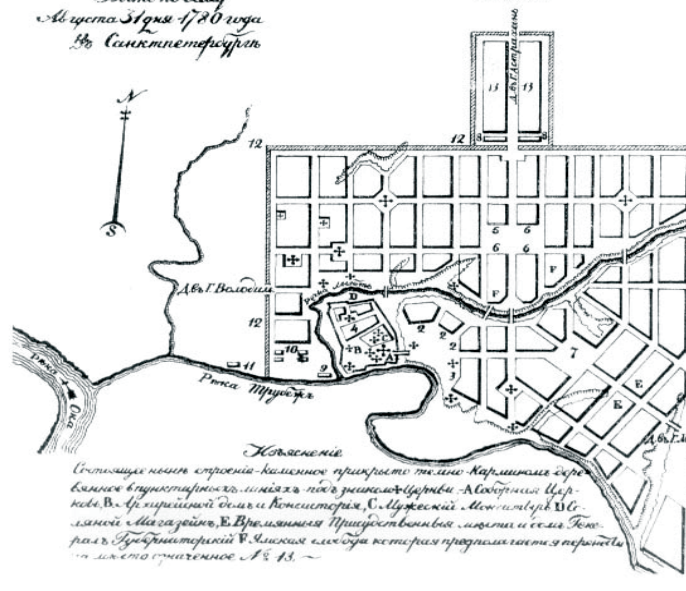

e)

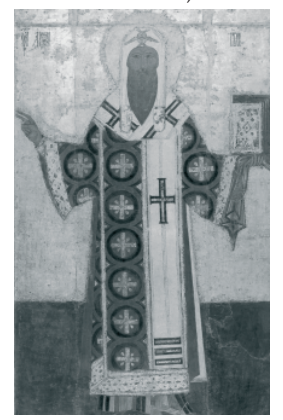

b)

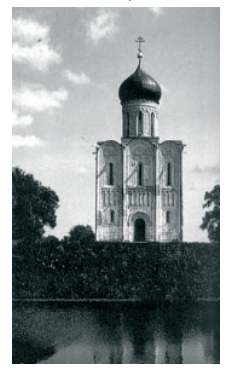

d) f)

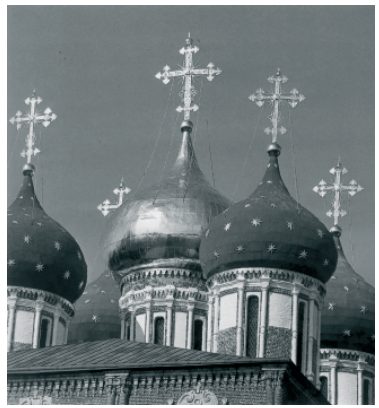

c)

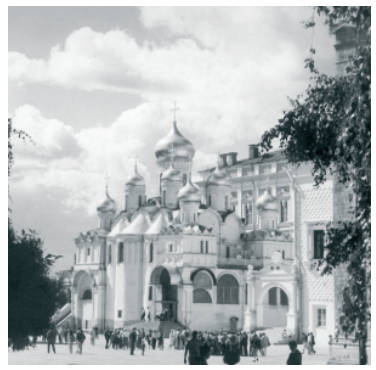

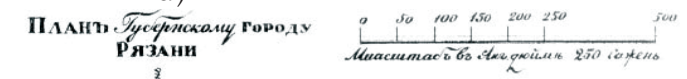

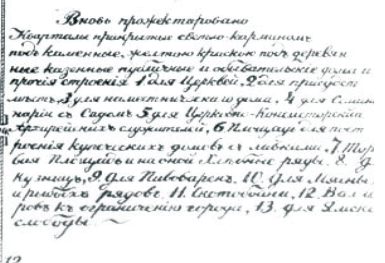

g)

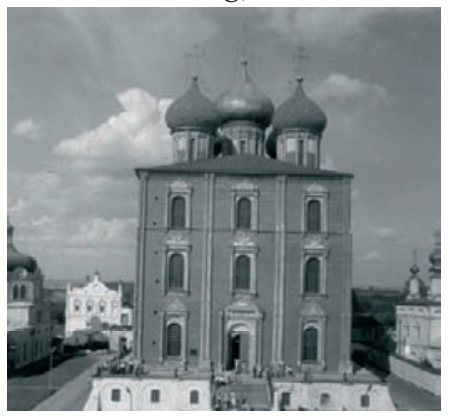

8 Konferencja zorganizowana przez Stowarzyszenie Konserwatorów Zabytków i Ministerstwo Kultury i Dziedzictwa Narodowego - Generalnego Konserwatora Zabytków w Warszawie, Pałac Kultury i Nauki 05-06.10.2006 „Polskie konserwacje poza granicami Rzeczypospolitej, referat; Konserwacje polskich architektów poza granicami kraju. Rewaloryzacja Placu Ghlebnaja Płoszczad w Riazaniu”, Wiadomości Konserwatorskie nr 20/2006. 
h)

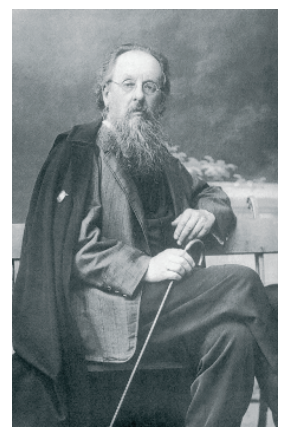

i)

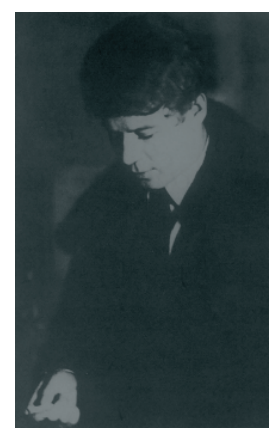

$\mathrm{k})$

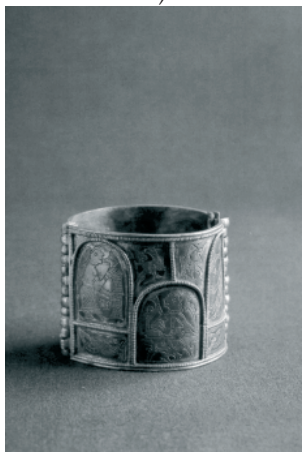

$\mathrm{m})$

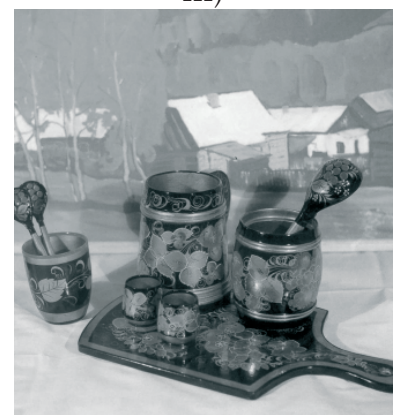

j)

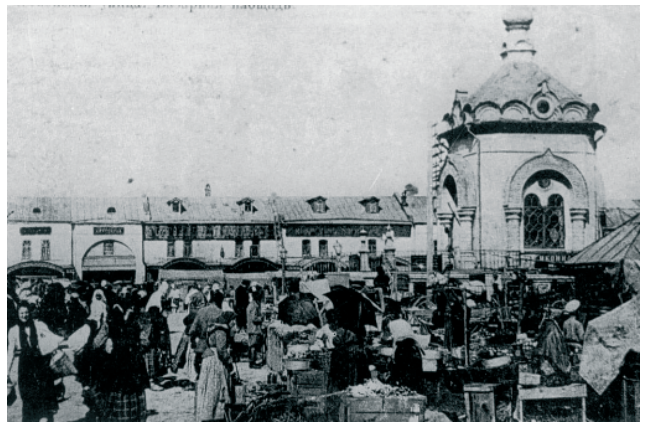

1)

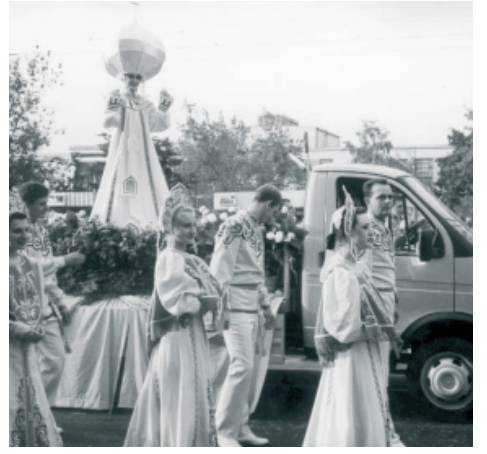

n)

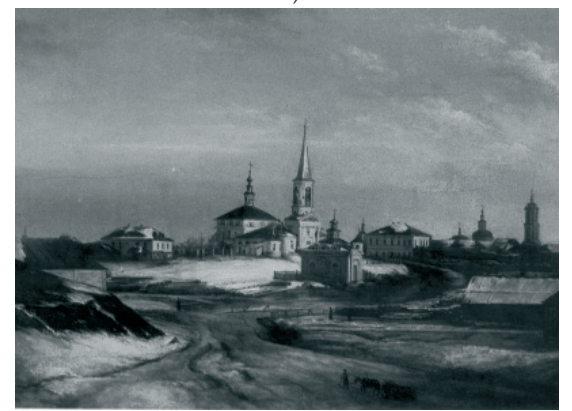

Phot. 2. a) Uspieński Monastyr (pierwsze groty skalne VIII w., przy drodze do Czufut-Kale), b) Sobór Wstawiennictwa Matki Bożej nad rzeką Nerlą (ok. 1165 koło Włodzimierza), c) Wzgórze Kremlowskie Moskwa. Cerkiew Zwiastowania, d) Generalny Plan miasta Riazania z roku 1780, e) Metropolita Aleksiej (ikona z XVI w., f) ,g) Kreml w Riazaniu, Uspieński Sobór, h, i) Wybitni mieszkańcy Riazania; Ciołkowski K.E. (1857-1935), Jesienin S.A. (1895-1925), j) XIX wieczny handlowy plac miejski, k) wyroby zdobnicze, 1) folklor, stroje ludowe, m) sztuka użytkowa, zdobione naczynia kuchenne, n) Riazań w sztuce Iwanow N. „Widok na plac starego targu” XIX w.

\section{Podsumowanie}

Współcześnie pojmowana ochrony środowiska zbudowanego to jej programowa rewitalizacja z jednoczesną aktywną konserwacją, biorącą pod uwagę długo- 
terminowe, historyczne poglądy ekspertów, współudział społeczności lokalnej oraz ekonomiczne potrzeby eksploatowania dziedzictwa kulturowego. Popularyzacja aktywnego uczestnictwa społeczności lokalnej w rozwój miasta, regionu, prowadzenie dialogu o świadome życie w środowisku zbudowanym jest drogą powszechnego inwestowania w edukację społeczną. Koniecznością czasu jest wdrażanie systemów powszechnej edukacji architektonicznej, oraz narodowego programu uświadamiania o współodpowiedzialności za środowisko w którym żyjemy. Demokratyzacja życia, umiejętność współżycia w społecznościach wielokulturowych, sprzyjać winna uaktywnianiu się sił społecznych wrażliwych i sprzyjającym postawom wobec środowiska i przestrzeni.

Dokonujące się zmiany systemowe $\mathrm{z}$ początkiem lat dziewięćdziesiątych w Europie środkowo-wschodniej, przechodzenie przez okres transformacji i programów dostosowawczych pobudzały w społeczeństwach tych regionów poczucie wielokulturowej odrębności lokalnej. Idea łączącej się Europy dała szansę wzajemnego wzbogacania się kultur o lokalne wartości, jednocześnie budząc obawy i niepokój przed otwarciem na ekspansywną monokulturę. Lokalne społeczności podejmują w tym czasie intensywne działania dla podkreślenia własnego „,rodowodu kulturowego" zlecając badania i studia dotyczące zaniedbanych na ich terenie obiektów historycznych i oczekując od środowiska architektów rozwiązań dla współczesnych, atrakcyjnych rynkowo funkcji (wzbogacając ich wartość) przy jednoczesnym poszanowaniu wartości kulturowych i przyrodniczych miejsca.

Pierwsze Konferencje Naukowe „Architektura bez granic” organizowane przez zespół powstającego kierunku Architektury na Politechnice Lubelskiej rozpoczął cykl badań dotyczących złożoności wielokulturowego pogranicza łączącej się Europy. W artykułach prezentowanych na zorganizowanych w tym cyklu konferencjach podkreślano wielokrotnie o konieczności identyfikacji miejsca w okresie globalizacji. ${ }^{9}$

9- Kozaczko M., Fazy globalizacji idei architektonicznych. Teka Komisji Architektury, Urbanistyki i Studiów Krajobrazowych, PAN o/Lublin, Vol.II, Lublin 2006 r.

- Pawlicki B. M. Architektura bez granic - peryferyjność czy uniwersalizm. Teka Komisji Architektury, UrbanistykI i Studiów Krajobrazowych, PAN o/Lublin Vo. III, Lublin 2006.

- Przesmycka E., (praca zbiorowa) Architektura sakralna $w$ ksztattowaniu tożsamości kulturowej miejsca, Lublin 2006.

- Raczak K., Kultura globalna, kultura lokalna. Teka Komisji Architektury, Urbanistyki i Studiów Krajobrazowych, PAN o/Lublin Vol. III, Lublin 2006.

- Wrana J., Identyfikacja miejsca jako wyzwanie w procesie globalizacji idei projektowych, Teka Komisji Architektury, Urbanistyki i Studiów Krajobrazowych, PAN o/Lublin, Vol.II, Lublin 2006 r.

- Wrana J., Architektura regionów przygranicznych - problem projektowania $w$ nowych warunkach europejskich (wsp. Zesp. Arch. Sergeya Filippova - Białoruś), Teka Komisji Architektury, Urbanistyki i Studiów Krajobrazowych, PAN o/Lublin, Vol. II, Lublin 2006.

- Wrana J., ,Trwałość tradycji kulturowych (..ty jesteś Piotr - czyli skała, na tej skale zbuduje kościół mój. Ewangelia wg. Św. Mateusza), świątynie na skale - Krym. Architektura sakralna w kształtowaniu tożsamości miejsca, (pod red. E. Przesmycka), Lublin 2006.

- Wrana J., LUBNY - kształtowanie tradycji na kresach. Teka Komisji Architektury, Urbanistyki i Studiów Krajobrazowych, PAN o/Lublin Vol. III, Lublin 2006.

- Zętar J., Architektura sakralna Lubelszczyzny jako przejaw wielokulturowych tradycji regionu. 


\section{Literatura}

[1] M. Angold, Cesarstwo Bizantyjskie 1025-1204. Historia polityczna. Wrocław 1993,

[2] Bakir T., Historical and archeological guide to Leptis Magna. Tripolis 1981.

[3] Bakir T. Leptis Magna, Tripolis 1981.

[4] Browning R., Justynian i Teodora, Warszawa 1977.

[5] Bujak A., RUŚ. Tysiąc lat chrześcijaństwa. Warszawa1992.

[6] Dué A, Dzieje 2000 lat Chrześcijaństwa, Edycja Świętego Pawła, Częstochowa, 2000.

[7] Gumiłow L. Od Rusi do Rosji. Szkice historii etnicznej. Warszawa 1996.

[8] Haynes D.E.L., Antiquities of Trypolitania, Trypolis 1981.

[9] Hatt P. K., Dzieje Arabów, Warszawa 1969.

[10] Hourani A., Historia Arabów, Gdańsk 1995.

[11] Johnson P., Historia Żydów, Kraków 2004.

[12] Kelm T., Architektura sakralna Sahary, Arkady 2000.

[13] Kotula T., Afryka Północna w starożytności. Wrocław 1972.

[14] Kotula T., Septymiusz Sewerus. Cesarz z Leptis Magna. Wrocław 1972.

[15] Mango C., Historia Bizancjum, Gdańsk 1997.

[16] Michajłowski E. B., Monuments of Architecture and Fine Arts, Moskwa 1985.

[17] Paszkiewicz H., Powstanie narodu ruskiego, Kraków 1998.

[18] Riazańskij Istoriko-Architekturnyj Muzej - zapowiednik, ..Cztoby nie prestała pamiat roditeli naszych $i$ nasza swiecza nie pogasła, izbornik, byli i predania riazańskogo kraja. Riazań- nowe wremia. (praca zbiorowa Riazań 1995).-

[19] Rybakow B., Pierwsze wieki historii Rusi. Warszawa 1983.

[20] Stępniewska-Holzer B., Życie codzienne na Bliskim Wschodzie w XIX wieku, PIW, Warszawa 2002.

[21] Zołotyj N. P., P E. W., Riazań 900-let. Riazań 1995.

[22] Żebrowski J., LIBIA. Warszawa1979.

Teka Komisji Architektury, Urbanistyki i Studiów Krajobrazowych, PAN o/Lublin Vo. III, Lublin 2006.

- Zętar J., Ośrodek „Brama Grodzka - Teatr NN” - odbudowa i ksztattowanie tożsamości miejsca. Teka Komisji Architektury, Urbanistyki i Studiów Krajobrazowych, PAN o/Lublin, Vol. II, Lublin 2006 r. 